\title{
Competing Inequalities: The Struggle Over Reserved Legislative Seats for Women in India*
}

\author{
LAURA DUdLEY JENKINS
}

Introduction of the Women's Reservation Bill was stalled in Lok Sabha on Monday amid unprecedented scenes of snatching of papers from the Speaker and the law minister and the virtual coming to blows of members [...]. As the shell shocked minister stood rooted to the spot, the member tore the papers with relish and flung them in the air provoking members from the treasury benches to storm the well. By this time, the well of the Lok Sabha looked like a veritable battle field with members from both sides preparing for a scuffle as the Speaker adjourned the House for the day. ${ }^{\text {I }}$

What caused such a commotion in the lower house of India's Parliament in July 1998? The Women's Reservation Bill was an attempt to reserve thirty-three per cent of seats in Parliament and state assemblies for women. In a society characterized by many forms of stratification, demands for subreservations within the category of "women" for other disadvantaged groups have repeatedly squelched the bill's progress. Defining which social categories should be eligible for such reservations leads to heated disputes because these questions involve both emotional commitments to group identities and material calculations of group interests.

"Reservations" in India are affirmative action policies for disadvantaged groups, allocating government jobs, and, in some cases, university admissions and legislative seats to such groups. The groups currently benefiting from reservations include the lowest castes, officially dubbed "scheduled castes" (SCs), and geographically isolated groups known as "scheduled tribes" (STs). Those receiving more limited benefits, which vary from state to state, include women and an intermediate category of certain lower-caste or lower-class groups called the "other backward classes" (OBCs). ${ }^{2}$ (The

\footnotetext{
* This article is based on my research in India as a Fulbright-Hays Scholar and in the United States as a United States Institure of Peace Scholar and MacArthur Scholar at the University of Wisconsin-Madison. The title is a tribute to, and a twist on, the title of Marc Galanter's classic work on compensatory discrimination in India, Competing Equalities. My thanks to Robert E. Frykenberg and Barbara Ramusack for encouraging me to historicize my political science and to Sushma Sharma, Kristy Bright and Tapati Bharadwaj for their assistance and support. Thanks also to all the women who invited me to join them at a New Delhi rally, inspiring me to study the issue of reservations for women in Parliament.

I. "RJD-SP Stall Introduction of Women's Quota Bill", Times of India, I4 July 1998.

2. For a more detailed description of these policies in comparison with other "affirmative action policies", see Laura D. Jenkins, "Preferential Policies for Disadvantaged Ethnic Groups: Employment and Education", in Crawford Young (ed.), Ethnic Diversity and Public Policy: A Comparative Inquiry (London, 1998).
} 
OBCs are generally better off than the "untouchable" SCs). Neither OBCs nor women currently have reserved seats in Parliament. An irony of these policies to help disadvantaged groups in Indian society is that competition over the allocation of benefits often divides groups that might otherwise work together to fight inequality. A case in point is the recent downfall of the parliamentary reservation proposal for women due to demands for a sub-quotas within the category of women for "other backward classes" (OBCs) and Muslims, a religious minority group. Each category is arguably made up of victims of historical discrimination and inequality; yet claims and counterclaims for reservations on the basis of sex, caste, class and religion have resulted in political gridlock. The politics of competing inequalities divides oppressed groups, which, if consolidated, have the potential to be numerically and politically dominant.

The issue of reserved legislative seats for women in India has reappeared, without resolution, at different historical moments. The following discussion includes three such moments: the debates over constitutional reforms in the last years of the British Raj, the disagreements over a major government report on the status of women in 1974, and the contemporary demand for the Women's Reservation Bill in the r990s. These disputes over women's reservations challenge current theories about identity politics, specifically theories of "post-materialism" and "new social movements". By linking benefits to certain identities, the issue of women's reservations throws into question assumptions that identity politics can be characterized as "post-material". A lack of class-based movements does not necessarily mark a post-material shift. As class-based movements, policies and analyses become scarcer, we need to develop new frameworks to recognize the material dimensions of identities other than "class". To do this, we can productively consider the long struggle over women's reservations in India, which demonstrates that the intersection between interests and identities whether based on gender, class or religion - is nothing new. After elaborating on how India's "competing inequalities" challenge current theories, this article will focus on pre- and post-Independence debates about reservations for women in order to draw conclusions about the need to "complicate the categories" of gender, class and religious identities.

\section{MATERIAL GIRLS: GENDER AND IDENTITY IN A MATERIAL WORLD}

The decline of socialist governments and class-based movements has sparked a search for new theoretical frameworks. At the same time, ethnic, gender and other "identity"-based movements are becoming more prevalent. These historical trends have contributed to literatures on "new social movements" and "post-material" politics. Scholars studying "new social movements", at first primarily in Europe, argue that social movements have shifted away 
from class-based issues toward post-material issues and identity politics. According to Larana, Johnston, and Gusfield,

[...] there is a tendency for the social base of new social movements to transcend class structure. The background of participants find their most frequent structural roots in rather different social statuses such as youth, gender, sexual orientation, or professions that do not correspond with structural explanations. ${ }^{3}$

Advocates of "post-material" explanations, again originally focusing on Europe, argue that a post-material value shift has resulted in the decline in class-based voting and rise of new social movements, such as women's or environmental movements, which cut across traditional classes by mobilizing around other forms of collective identity and interests. ${ }^{4}$

Although injecting a needed dose of culture into analyses too often driven by economic explanations, the new social movements literature often swings too far in the other direction. Advocates have argued, for example, that new social movements around collective identities are "essentially cultural in nature". The division between European "new social movements" and American "resource mobilization" approaches to social movements has contributed to the failure to synthesize. cultural and economic analyses. Resource mobilization theorists emphasize the material incentives, opportunities and strategies of rational actors at a given moment to explain the rise of social movements. The new social movements literature's focus on collective identities constrasts with the American approach, governed by a rational action paradigm inspired by economics. Neither approach adequately addresses class, and, even if paying lip service to both economic and cultural factors, neither framework effectively incorporates both. ${ }^{6}$ It is time to turn to different regions and new approaches.

The study of non-Western societies complicates conclusions that we are entering a post-class phase of history, let alone a post-material phase.

3. Enrique Laraña, Hank Johnston, and Joseph R. Gusfield, New Social Movements: From Ideology to Identity (Philadeiphia, PA, 1994), p. 6.

4. Ronald Inglehart, Culture Shift in Advanced Industrial Society (Princeton, NJ, 1990).

5. Kenneth D. Wald, James W. Button and Barbara A. Rienzo, "The Politics of Gay Rights in American Communities: Explaining Antidiscrimination Ordinances and Policies", American Journal of Political Science, 40 (1996), p. 1169.

6. An example of classic "resource mobilization" scholarship is Craig J. Jenkins, The Politics of Insurgency: The Farm Worker Movement in the rg6os (New York, 1985). Doug McAdam's "political process" model builds on this tradition. See Doug McAdam, Political Process and the Development of Black Insurgency 1930-1970 (Chicago, IL, 1982). Some have called for a bridge between the European and American approaches: Bert Klandermans and Sidney Tarrow, "Mobilization into Social Movements: Synthesizing European and American Approaches", in Bert Klandermans, Hanspeter Kriesi and Sidney Tarrow (eds), From Structure to Action: Comparing Social Movements Across Cultures (Greenwich, CT, 1988). Subsequent work creatively engaging in such a synthesis has, nevertheless, tended to remain primarily in one camp, as in Sidney Tarrow's tendency to reduce culture to a "cultural tool chest" exploited by political entrepreneurs: Sidney Tarrow, Power in Movement: Social Movements, Collective Action and Politics (Cambridge, 1994). 
Research on women and on non-Western societies pose the greatest challenges to assumptions about "post-materialism" and "new social movements". Feminist scholars have rightly pointed out that most women's movements, whether in Western or non-Western societies, cannot be accurately characterized as "post-material" movements, due to their involvement in issues of wages and work, or, in many cases, subsistence and survival. The notion of "new social movements" has been used in political analyses of the developing world, most often Latin America but also India. Analysis of "new social movements" in India demonstrates that identity-based movements are neither completely "new" nor "post-material" in these contexts." Since many scholars of post-materialism and new social movements make no claim that these theories hold true in the developing world, this article will not try to debunk them through examples from India. Rather, due to the failure of European and American approaches to adequately synthesize cultural and economic factors or address the intersections of class, gender and other forms of identity, this article draws on India to illustrate the continuing salience of all these forms of identity and the danger of dichotomizing "material" politics, too often simply equated with class, and "post-material" politics, too often equated with gender and ethnicity. Even scholars focusing on the Western world are becoming uncomfortable with the artificial division berween the politics of recognition (of different identities) and the politics of redistribution (of material resources). ${ }^{8}$ The following analysis of "competing inequalities", based on rival demands for both group recognition and power redistribution, presents an alternative to post-materialism for scholars of both Western and non-Western societies.

India is a particularly rich case in this regard due to its extreme cultural diversity and material disparities. Solidarities are constantly emerging and shifting on the basis of both the emotional pull of certain identities and rational calculations of interests. People have multilayered identities, which can include gender, class, caste, race, religion, ethnicity as well as many others, but material considerations may highlight one facet of identity. As Madhu Kishwar, an Indian feminist, writes, "A group or person may begin to assert a particular identity with greater vigour if it provides greater access to power and opportunities." For example, Indian women at various times have asserted their identity as women in order to demand reserved legislative

7. Gail Omvedt, Reinventing Revolution: New Social Movements and the Socialist Tradition in India (Armonk and London, 1993). See also Arturo Escobar and Sonia E. Alvarez (eds), The Making of Social Movements in Latin America: Identity, Strategy and Democracy (Boulder, CO, 1992) and Alfred Stepan (ed.), Democratizing Brazil: Problems of Transition and Consolidation (New York, 1989).

8. Catherine Hoskins and Shirin M. Rai, "Gender, Class and Representation: India and the European Union", European Joumal of Women's Studies, 5 (1998), pp. 345-365. See in particular their discussion of Iris Marian Young's work on "unruly categories".

9. Madhu Kishwar, "Who Am I? Living Identities vs. Acquired Ones", Manushi, 94 (1996), p. 6. 
seats. The political power associated with these seats has important material dimensions, including the opportunity to have a say in the distribution of state resources. Women in elected office are in a position to try to "improve their access to the resources that count, from education and credit to the ownership of land and housing". ${ }^{10}$

This current demand for women's reservations does not differentiate between privileged women and $\mathrm{OBC}$ or Muslim women. Although "women" do not constitute a universal category, for political purposes women sometimes choose to "act as if such a category indeed exists, precisely for the reason that the world continues to behave and treat women as

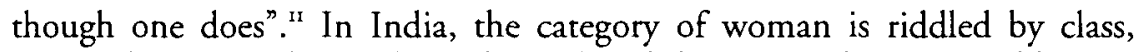
caste, religious, and countless other cultural divisions. The current dilemma facing the Indian women demanding reserved seats in Parliament is that such a demand may not adequately recognize these other categories; on the other hand, opening the Pandora's box of sub-quotas has mired the Women's Reservation Bill in endless debates over which groups of women should receive their own categories of reservations.

The following discussion focuses on the overlapping, and yet competing, categories of women, OBCs, and Muslims. Some clarification of these categories, particularly the OBCs, is in order. The women in India who have been most actively demanding the right for parliamentary reservations have been largely although not exclusively from upper-class Hindu backgrounds. The "other backward classes" are an official category in India, made up of groups - "other" than the scheduled castes and scheduled tribes - recognized as eligible for preferential policies in the Indian constitution. Each state draws up lists of groups that qualify as OBCs. They are generally lists of Hindu lower castes which are not as low as the "untouchable" scheduled castes, as well as some low-caste-like groups within other religions. The use of the term "classes" in this context means that the distinction between "caste" and "class" has become subject to legal as well as sociological debare in India. ${ }^{12}$ Suffice it to say that caste and class have some sociological similarities, both referring to groups within a status hierarchy, often involving occupational distinctions. A "caste" or jati distinction is more likely to be based on religious ideology and the notion of status being determined at birth. Classes on the other hand could, in theory, encompass many different jatis and other groups. The term class, as in the official term "backward classes", is used not just as a euphemism for caste but also serves as a more inclusive term than caste. For example, disadvantaged groups of Muslims

Io. Jane S. Jaquette, "Women in Power: from Tokenism to Critical Mass", Foreign Policy, 108 (I997), pp. 23-27.

II. Rosalind O'Hanlon and David Washbrook, "After Orientalism: Culture, Criticism, and Politics in the Third World", Comparative Studies in Society and History, 34 (1992), p. I54.

12. A.M. Shah, "The Judicial and Sociological View of the Other Backward Classes", in M.N.

Srinivas (ed.), Caste: Its Twentieth Century Avatar (New Delhi, 1996), pp. 174-194. 
can be included on $\mathrm{OBC}$ lists. Some states have reserved jobs and university admissions for $\mathrm{OBCs}$ since long before Independence, yet national reservations of central government jobs have only recently been extended to this group in the last decade. This controversial policy precedent and the growing political power of the $O B C$ s spurs demands for reserved seats for $O B C$ women in Parliament. Some argue that the OBCs may be forming a lowerto middle-"class" challenge to established power hierarchies, but the OBCs are still quite regionally-based and divided. ${ }^{13}$ The following references to "class" must be considered in light of these complex relationships between class and caste. Muslims in India are a socio-economically disadvantaged group, particularly since partition, when much of the Muslim elite had the resources to go to Pakistan, leaving a smaller and even more disadvantaged religious minority in India. Although Muslims had special rights under the British, only those Muslim communities classified as "backwards" currently benefit from national level reservations. Neither women, OBCs, or Muslims currently get reserved seats in Parliament. ${ }^{\mathrm{I}}$

How do India's gender-, class- and religion-based demands for reservations pose an alternative to the theories of "post-material" identity politics and new social movements? These literatures assume that the decline of class-based politics equals "post-materialist" politics, thus ignoring the economic aspects of gender identity, to say nothing of the cultural aspects of class identity. The link between group benefits and all kinds of identities in India belies this false dichotomy between class versus other, purportedly post-material, identities. India's complex intersections of identities, resulting in competing arguments that some groups are more unequal than others," demonstrate the need to "complicate the categories" not only in social analysis but also social policy.

\section{"MINOR MINORITIES": CONTESTED CATEGORIES AND WOMEN'S RESERVATIONS IN HISTORICAL PERSPECTIVE}

The demand for women's reservations in legislative bodies is not new; neither is the controversy over the appropriate categories to use when allocating reservations. Pre-Independence precedents touch on similar issues to those being raised today. Legislative reservations for women were under discussion during debates in the 1920s and 1930s over constitutional reforms for India. At that point, too, the category of women took a back seat to other categories, such as religion and caste, in the eyes of British officials in

13. Francine R. Frankel, "Middle Classes and Castes in India's Politics: Prospects for Political Accommodation", in Atul Kohli (ed.), India's Democracy: An Analysis of Changing State-Society Relations (Princeton, NJ, 1988), pp. 225-26I.

I4. For a detailed discussion of these categories and reservation policies for them see Marc Galanter, Competing Equalities: Law and the Backward Classes in India (Delhi, 1991). 
London and New Delhi. One went so far as to place "female suffrage and legislative seats in the category of minor minorities" (religious communities such as Muslims and Sikhs and caste groups such as the so-called "untouchables" were considered the major minorities). ${ }^{\text {is }}$ A classic example of competing inequalities is this division of "minorities" against themselves.

In the last decades of colonial rule, Britain granted Indians limited rights to serve as representatives in legislative bodies. In part an effort to neutralize nationalists and expand the "circle of collaborators", such policies also contributed to "divide and rule" tactics by giving special electoral rights to certain groups. ${ }^{16}$ These policies include the 1909 Indian Councils Act (based on the Minto-Morely Report), the 1919 Government of India Act (based on the Montagu-Chelmsford Proposals), and the 1935 Government of India Act. This period also saw the first attempts at forming "All-India" women's associations, such as the Women's India Association (WIA) in 1917, followed by the All India Women's Conference (AIWC) and the National Council of Women in India (NCWI). These major women's associations tried to influence the new policies by passing resolutions, sending delegates to conferences, submitting memoranda and letters, and lobbying various decision makers. Their primary agenda was gaining the right to vote for Indian women, but they became involved in the issue of reserved seats for women in legislatures. Ironically, although these major Indian women's organizations came down against such reservations, they were granted to them in I935.

At that point some "major minorities" had already received reserved seats, as well as separate electorates, meaning only members of the community in question could vote for candidates for their reserved seats. Muslims received separate electorates under the Government of India Act of 1909. The Government of India Acts of 1919 and 1935 granted Muslims, Sikhs, and Christians separate electorates. "Depressed classes" (lower-caste groups) were provided a few nominated seats in 1919, more in 1925, and even more elected seats in $1932 .{ }^{17}$ These proliferating categories, nationalists argued, facilitated continuing British control.

Concerned about divisions within the nationalist movement, the Indian National Congress (the leading nationalist organization) objected to special electoral rights for any of these groups. The major women's organizations, in turn, came to oppose similar proposals for women. Women associated with other political organizations held a different position. Muslim activist Begum Shah Nawaz, for one, agreed with the Muslim League's support for reserved seats and special constituencies for Muslims. She also supported

I5. Barbara Ramusack, "Cultural Missionaries, Maternal Imperialists, Feminist Allies: British Women Activists in India, 1865-1945", Women's Studies International Forum, 13 (1990), p. 316.

16. Janaki Nair, Women and Law in Colonial India (New Delhi, 1996), p. I22.

17. Galanter, Competing Equalities; Thomas R. Metcalf, Ideologies of the Raj (Delhi, 1995). 
reservations for women. When the Congress boycotted the first roundtable conference on constitutional reform in 1930, Nawaz and another nonCongress female delegate, Mrs. Subbarayan, submitted a memorandum in favour of reserved seats for women, arguing that "we regard the phrase 'a fair field and no favour' at the present time as an illusory one ${ }^{n} .{ }^{18}$ The major women's associations denounced them.

When the Congress decided to participate in the second roundtable conference on constitutional reform in 1931, a very different women's delegation introduced a joint memorandum of the AIWC, NCWI and WIA. This stated that "to seek any form of preferential treatment would be to violate the integrity of the universal demand of Indian women for absolute equality of political status" ${ }^{19}$ Initially the WIA supported reservations for women as a "transitional necessity" but subsequently it signed onto the joint resolution, an example of a nationalist agenda superseding concerns specific to some women. ${ }^{20}$ The WIA's Muthulakshmi Reddi subsequently wrote in opposition to reservations even for lower castes (who had been granted reservations as "depressed classes") in Indian society, for the sake of a "common platform": the "only way to bring the Brahmans, the women and the pariahs together on a common platform is by enfranchising the women and the depressed classes on equal terms with others" ${ }^{21}$ Thus Congress and the major women's associations opposed reservation policies that would recognize distinct social categories within the Indian "nation", whether those categories were based on religion, gender, class or caste.

Ignoring the stance of the major Indian women's organizations, the Government of India Act of I935 granted women forty-one reserved seats in the provincial legislatures, as well as limited reservations in a central legislature. ${ }^{22}$ This puzzling decision may be due to the influence of Eleanor Rathbone and other British advocates for the rights of Indian women, or it may be an example of the British taking their commitment to group-based policies to its logical end. In any event, despite their dim view of such a "minor minority", the British added women to the list of groups with special electoral rights. Yet, their overriding concern with the major minorities

18. Gail Pearson, "Reserved Seats - Women and the Vote in Bombay", in J. Krishnamurty (ed.), Women in Colonial India: Essays on Survival, Work and the State (Delhi, 1989), p. 205.

19. Pearson, "Reserved Seats - Women and the Vote", p. 207.

20. Ibid., p. 206. On the relationship between the nationalist and women's movements in India, see also Nair, Women and Law in Colonial India, and Partha Chatterjee, "The Nationalist Resolution of the Women's Question", in Kumkum Sangari and Sudesh Vaid (eds), Recasting Women: Essays in Indian Colonial History (New Brunswick, NJ, 1989), pp. 233-253.

21. Pearson, "Reserved Seats - Women and the Vote", p. 208.

22. The proportion of women elected to the central legislature under this plan was only 3.4 per cent; Government of India, Ministry of Education and Social Welfare, Department of Social Welfare, Towards Equality: Report of the Committee on the Status of Women (New Delhi, 1974), p. 356 . 
affected even the women's reservations, which were subdivided on a religious basis, with certain women's seats reserved for Muslim women. This minute division of the electoral pie brought out tensions along both gender and religious lines. The major women's organizations, such as the AIWC, including its Muslim women members, protested that "the communal award will divide us, Indian women ${ }^{7}{ }^{23}$ On the other hand, the prominent Muslim Begum Shah Nawaz continued her support of reserved seats for both Muslims and women. Some male members of "major" minorities, however, were rather disgruntled at having their quotas diluted by women. Muslim leaders in Punjab, for instance, were "angry that of the few seats for Muslims, one was reserved for a woman" ${ }^{24}$ Muslim women in particular fell between the cracks of the "major" and "minor" minorities during this period prior to Independence and the partition of India and Pakistan; in addition to facing such resistance from Muslim men, some Muslim women were becoming estranged from the Hindu-dominated women's movement. ${ }^{25}$

When granted reservations despite their own protests, women's associations made the most of the situation. The AIWC initially considered refusing to participate in the new constitutional provisions, but eventually it officially resolved to take advantage of them. Various women's groups even lobbied for additional seats in their areas. In the 1937 elections fifty-six women became legislators, forty-one in reserved seats; ten were in unreserved seats and five in nominated seats. Most were relatively wealthy Congress candidates.

After Independence in 1947, the new government only retained the legislative reservations for the scheduled castes and scheduled tribes in the lower house of Parliament, the Lok Sabha, and the lower houses of the state legislatures, the Vidhan Sabhas. ${ }^{26}$ The post-Independence constitution did not reserve any legislative seats for the other backward classes, religious minorities, or women. The constitution also outlawed separate electorates for national and state assemblies, so the general electorate voted for candidates for reserved seats. ${ }^{27}$ Ironically, although the major women's organizations opposed women's reservations, and the reservations themselves were quite short-lived, they gave elite, nationalist women a foothold in Indian legislative life.

23. Pearson, "Reserved Seats - Women and the Vote", p. 210.

24. Geraldine Forbes, Women in Modern India (Cambridge, 1996), p. 196.

25. Ibid., pp. 196-203.

26. Anglo-Indians also got a few nominated seats.

27. The Indian Constitution (1950) granted adult suffrage, so women were included in the electorate. Prior to this, the British Southborough Committee had left the issue of women's suffrage up to the provincial legislatures, after which "each of the Indian provincial legislatures voted to make it possible within a short span of time for women to be represented at par with men", writes Madhu Kishwar, "Women and Politics: Beyond Quotas", Economic and Political Weekly, 26 (1996), pp. $2867-2874$. 


\section{COMMUNITIES AND CATEGORIES: TOWARDS EQUALITY AND THE RENEWED DEBATE OVER WOMEN'S RESERVATIONS}

Independence brought a "lull" in feminist campaigns. ${ }^{28}$ The Indian National Congress became the ruling Congress Party. It incorporated a number of feminists into the government. The 1950 constitution declared women to be equal and granted them the right to vote. But optimism about freedom and "modernization" in the early years of independence gradually waned as the status of women seemed to stagnate or even decline. In spite of dramatic exceptions, such as the election of Indira Gandhi as prime minister in 1966, most women did not achieve the equality formally granted to them. In the early seventies, the government of India did a comprehensive study of the status of Indian women. The resulting 1974 report of the Committee on the Status of Women in India, Towards Equality, must be considered in any discussion of women's reservations for two reasons. First, no other similarly comprehensive government report on women in India exists. Second, the issue that most divided the committee was legislative reservations for women.

With the Western feminist movement at its peak in the early seventies, the United Nations started to focus more on the status and development of women in low-income countries. Partly in response to this new UN agenda, the government of India in 1971 formed the Committee on the Status of Women in India in order to gather new data as well as compile and analyze existing information. ${ }^{29}$ This report was released in time for the 1975 observance of the International Women's Year. In addition to the international push for reconsideration of women's status, Indian women began to push for change during the seventies. Both the report and the renewed activism brought the status of women back into national debate. The woman in charge of the report, political science professor Veena Mazumdar, was previously uninvolved in the women's movement. But she was so appalled by her findings that she became a leading figure in the "new wave ${ }^{\text {}}$ of Indian feminism. ${ }^{30}$

Towards Equality reported on women's demographic, sociocultural, legal, economic, and educational status, evaluated current programs and policies and made several recommendations. Although a government report, it was quite critical of the government. It addressed the economic plight of many

28. Radha Kumar, "From Chipko to Sati: The Contemporary Indian Women's Movement", in Amrita Basu (ed.), The Challenges of Local Feminisms: Women's Movements in Global Perspective (Boulder, CO, 1995), p. 60.

29. Elisabeth Bumiller, May You Be the Mother of a Hundred Sons: A Journey Among the Women of India (New York, 1990), p. 126. Another example of the rising UN interest in women's rights during the seventies is the 1979 Convention on the Elimination of All Forms of Discrimination Against Women.

30. Bumiller, May You Be the Mother of a Hundred Sons, pp. 125-127. 
women since Independence and the reluctance of legislators to put constitutional ideals into practice. "Large sections of women have suffered a decline of economic status", it concluded. "Every legal measure designed to translate the constitutional norm of equality or special protection into actual practice has had to face tremendous resistance from the legislative and other elites. ${ }^{31}$ Such findings set the stage for the debate in the committee over reserved seats for women in legislative bodies. Those in charge of the report, like Mazumdar, came from backgrounds far more privileged than those of most Indian women, yet the report attempted to reflect diverse viewpoints. The issue inspiring the most divergent viewpoints, necessitating the addition of several "notes of dissent" at the end, was legislative reservations for women.

Mazumdar and her committee, particularly those from the "preIndependence generation", initially had no intention of considering the issue of legislative reservations for women. In the tradition of the nationalist women's organizations, they had "never been supporters of special representation or class representation in any form". They still associated such reservations with colonial strategies and "in academic discussions we had often criticized the system of reservations for scheduled castes and scheduled tribes as a legacy of the historical period which institutionalized the backwardness of certain sections of our population". The committee's initial interviews and surveys did not include any questions on the issue of reservations for women. "Only when the problem kept being posed repeatedly before us by various groups of women in the course of our discussions did we become aware that a problem like this was real", Mazumdar confessed. ${ }^{32}$ By the release of the report, Mazumdar had embraced the concept of legislative reservations. She even personally espoused reservations in Parliament, going beyond the committee's recommendation to limit them to the municipal level. Towards Equality signalled a shift towards more open acceptance of reservations among some women, even those previously opposed to such measures. At the same time, the committee was very guarded in its limited endorsement and included many familiar arguments against reservations. Though summarizing arguments for reservations up to the level of Parliament, the committee as a whole concluded that they could not recommend such a step.

Major arguments against reservations for women continued to involve concerns about other unequal groups, namely religious minorities and lower classes and castes. Two types of arguments along these lines emerged in the debate over Towards Equality. One argument was that the inequalities faced by these other "communities" outweighed those faced by the "category" of women. This argument parallels the British distinction between major and 
minor minorities and subsequent decisions to grant women's reservations at a later date than those for other groups, and then only within communal subdivisions. A second type of argument has precedents in the nationalist movement's anti-reservation stance. Concerns about national unity continued after Independence. This critique raised the spectre of national disintegration in the wake of such official distinctions between groups, be they religious-, class-, caste- or gender-based.

The report's conclusions draw on both types of arguments against reservations, prioritizing "communities" over "categories" and expressing concern about national integrity. In terms of communities, it considered fallacious "the entire argument for separate representation for women. Women's interests as such cannot be isolated from the economic, social and political interests of groups, strata and classes in the society. ${ }^{{ }_{33}}$ This conclusion depended on a critique of the "category" of women, which in contrast to other groups, did not constitute "a community". The committee admitted, "Though they have some real problems of their own, they share with men the problems of their groups, locality and community. Women are not concentrated in certain areas confined to particular fields of activity. Under these circumstances, there can be no rational basis for reservation for women. ${ }^{34}$ Although not using the word "caste", the committee contrasted the plight of women with the spacial and occupational segregation characterizing the caste system. Notably, the word "community" in the Indian context had become a common euphemism for castes and religious groups, reinforcing the committee's distinction between women as a category and other groups as communities.

The committee further included the national unity argument against reservations: "Such a system of special representation may precipitate similar demands from various other interests and communities and threaten national integration. ${ }^{n 5}$ In spite of these concerns, it made some limited recommendations for reservations for women at the local level as a "transitional measure". This careful choice of phrase echoed the WIA's initial support of reservations for women in I93I as a "transitional necessity", prior to their decision to join with the other two major women's organizations in opposition to reservations.

Even the recommendation of limited and local-level reservations sparked notes of dissent, appended to the report. Phulrenu Guha seconded the committee's discomfort with prioritizing the category of "women" over class divisions by arguing that "there is a possibility that reservation of seats will

33. Ibid., p. 304. Examples in this report of the arguments for legislative reservations include the need for political empowerment of women to precede socio-economic empowerment in the Indian context, the need to compel political parties to shift strategies in candidate selection, and the value of "a body of spokesmen of the women's cause" in legislatures. See pp. 302-303.

34. Ibid., p. 304 .

35. Ibid. 
only help women of a particular class who are already privileged. It should be our aim to see that the masses of women of all classes become equal partners with men in all senses in our society." Guha's dissent also embraced the national unity argument that "this type of reservation of seats might lead other communities/classes to argue for reservation of seats. This, to my mind, will encourage separatist tendencies and hamper national integration. ${ }^{n 6}$

In another note of dissent, Vina Mazumdar and Lotika Sarkar felt the report did not go far enough and advocated reservations at higher levels. They claimed that the number of women in Parliament was still less than five per cent, only marginally higher than the proportion elected in the central legislature after the 1935 Government of India Act. These dissenters discounted the "community versus category" critiques of women's reservations, arguing that helping women will help the women of various communities as well. "Larger numbers" of women in Parliament, they proposed, "will also help to break the somewhat exclusive class composition of this group" ${ }^{37}$ Mazumdar and Sarkar also rebutted the national unity argument, or, as they described it, "the argument that special representation might precipitate fissiparous tendencies". Here they actually deployed the idea that women are a category and not a community to defend the notion of special reservation. Contrasting women with other minority groups, they argued that reservations for women could not create the "isolated pockets" feared by critics of reservations. ${ }^{38}$

Although the rhetoric shifted from a distinction between "major" and "minor" minorities to one between "communities" and mere "categories", the Committee on the Status of Women continued the tradition of ambivalence towards women as a unitary category for public policies. From the beginning the report noted that "the inequalities inherent in our traditional social structure, based on caste, community and class have a very significant influence on the status of women in different spheres". ${ }^{39}$ One legacy of colonial policies was the continuing primacy of caste and religious communities as the groups needing special attention, even in the eyes of many members of the Committee on the Status of Women. This viewpoint countered demands for a special reservation for "women" as a group. Since Independence, fears that the nationalist movement might disintegrate had transformed into fears that the nation might disintegrate. This viewpoint countered demands for reservations in general. Both types of arguments, with their roots in the colonial era, limited the success of the continuing demands for women's reservations. Ironically, some low-caste organizations

36. Ibid., p. 354. This quotation is from Phulrenu Guha's "Political Status: Note of Dissent". 37. Ibid., p. 357. This quotation is from Lotika Sarkar and Vina Mazumdar's "Political Status: Note of Dissent".

38. Ibid.

39. Ibid., p. 3 . 
in the seventies drew parallels between their oppression and women's, undeterred by the continuing official distinctions between communities and categories..$^{\circ}$ Yet the more frequent pattern of activism by women and other disadvantaged groups was a continuing division between urban elite organizations and rural, grassroots movements.

The proposal for local-level reservations for women eventually became part of the 73rd Constitutional Amendment Act - an attempt to revitalize the local government system known as panchayati raj. Initially introduced by prime minister Rajiv Gandhi in 1989, the amendment passed in 1993. The village panchayats or councils must reserve one third of their seats for women and also reserve seats for "scheduled castes and tribes" in proportion to their populations in that area; one third of SC and ST seats are reserved for SC and ST women. ${ }^{41}$

The support of Rajiv Gandhi and others from the Congress Party, like former government minister Margaret Alva, marked a further shift from the former abhorrence of reservations as a nationally divisive policy. Alva reintroduced the demand for reservations on all levels, including Parliament, in the 1980 s when she was Minister for Women. She viewed the thirty-three per cent reserved seats for women in the panchayats as a stepping stone to reservations in Parliament. "Let us start with the panchayats", she declared. "Instead of taking on everybody, let's start with the panchayats and see how it runs, and then move upwards." Alva felt such gradualism would quell the doubts of those who believed that "you won't find women to contest, you know; they are not educated; they are not trained. How do they do it?" ${ }^{32}$ Later Alva could point to the success of the initiative:

In the course of the last three years, between ' 93 and ' 96 , one million women have been elected to local bodies. Now one million [...] is more then the population of some countries. But one million women today are elected representatives in local bodies all over the country. Now just imagine if one million have been elected, at least five million have contested [...] five million women have gone through the political process. ${ }^{43}$

The adoption of this constitutional amendment, with the endorsement of major members of the Congress Party, signalled the increasing acceptability of women's reservations; yet numerous bills attempting to extend such reser-

40. Kumar, "From Chipko to Sati", p. 63.

41. Hoshiar Singh, "Constitutional Base for Panchayati Raj in India: The 73rd Amendment Act", Asian Survey, 34 (1994), pp. 824-825; P.M. Bakshi. The Constitution of India: With Selective Comments by P.M. Bakshi (Delhi, 1996), pp. 182-183.

42. Author's interview with Margaret Alva, former government minister, 19 December 1996, New Delhi. Alva was appointed to the upper house of Parliament by Indira Gandhi in 1974. She later was appointed by Rajiv Gandhi as head of the women's department within the Ministry of Human Resource Development. She has also served as Minister of State for Youth Affairs, Sports and Women.

43. Author's interview with Margaret Alva, ig December 1996, New Delhi. 
vations to the national level failed. The major arguments against these latest proposals repeated those of the past.

\section{"ELECTED BODIES": WOMEN'S RESERVATIONS IN THE NINETIES}

It's a step but it's not going to deal with all the problems that women face because, then again, politics is not only elected bodies. Politics is what's happening around you and how you're treated on the streets.

Feminist leader Brinda Karat, on reservations for women. ${ }^{44}$

How women are treated can vary due to class, caste or religion, but organizing a movement or a policy on the basis of such nuances is difficult. The 1990 s brought several movements pushing for more equal representation into conflict with each other. The competing demands of women, OBCs, and Muslims for their own legislative reservations have led to political gridlock. In 1990, the Indian government granted reservations in central government jobs, though not in the legislature, to the OBCs. This recognition has given the previously more diffuse class- and caste-based critiques of women's reservations a political grounding. Like the 1998 scene in the Indian Parliament previously described, an earlier 1996 attempt to introduce a women's reservations bill succumbed to squabbling over recognition of the OBCs within the category of women..$^{45}$ Muslim demands for reservations have also competed with women's demands. The "competing inequalities" of gender, class, caste and religion have delayed a purely gender-based reservation scheme at the national level.

Key proponent of the women's reservation bill, Margaret Alva, argued for the legal recognition of women as a legitimate category for reservations. "Whether one is fighting for the scheduled castes, the backward classes, or the minorities - the largest group that is effected is women", she contended. "Women are the single largest group of backward citizens in the country. ${ }^{46}$ Other women have been more critical, even while supporting the bill, as

44. Author's interview with Brinda Karat, women's movement leader (AIDWA), CPM (Communist Party-Marxist) political activist, to December 1996, New Delhi.

45. The Constitution (Eighty-First Amendment) Bill, 1996. See debates in the Lok Sabha of 13 September 1996, when MP Madhukar Sarpotdar argued as follows: "Would the skies have fallen on the nation if it [the Eighty-First Amendment Bill] had been kept pending or had been referred to a Select or Standing Committee and then, once and for all, a comprehensive Bill in this regard was brought forward? [...] It should have been brought after involving every section and after proper deliberations. Today the Scheduled Castes, the Scheduled Tribes have been involved but what about the people from the Other Backward Classes who have not been included in this bill?"

46. Congress MP and former government minister Margaret Alva, quoted in Meenakshi Nath, "Cutting Across Party Lines: Women Members of Parliament Explain Their Stand on Reservation Quotas", Manushi, 96 (1996), p. II. 
the views of leftist activist Brinda Karat and Hindu nationalist Uma Bharati indicate.

The major critiques of parliamentary reservations for women again distinguish between the claims of the "major minorities" or "communities" and those of women. "National unity" is less prominent than in previous debates. Some critics do not want to thwart the bill but to point out its limitations for backward classes and Muslims. Their concerns are reminiscent of Towards Equality and its recognition of diversity within the category of women. Other critiques come from incumbent politicians, who have suddenly raised similar objections in order to quash the bill on the floor - in spite of the decision of every major party to support the bill in their 1996 party platforms. Such tactics resemble group-based policies under the British, which strategically both divided and appeased various groups. By endorsing the bill in party platforms but failing to pass it out of a sudden concern for backwards citizens or Muslims, politicians court the women's vote, the backwards vote, the Muslim vote and simultaneously protect their own seats. Notably, any new reservations would unseat many incumbents.

Some of the more well-intentioned critics have analysed the condition of the backward women under the new local-level reservations in order to emphasize the limits of such policies. For example, although she holds that even lower-caste women have benefited a great deal from reservations in local councils, feminist and leftist (Communist Party of India-Marxist) activist Brinda Karat noted that reservations are not always enough to grant them access. She lamented the progress and predicaments of a subcategory of women, the scheduled castes:

What we are finding is scheduled caste women who would never have been given an opportunity to come into [...] politics, are now coming in. Unfortunately, in many, many cases, they are, just as the scheduled caste men have been all along, just a rubber stamp [...] They are not allowed to participate [...] we had cases, where they hold the meeting deliberately in the house of an upper caste person, so the scheduled caste women, because of the social immobility, would censor herself [...] and so she will be sitting outside and they would send her the register and she would put her thumbprint on it. And so you see reservation on its own cannot be an instrument to remove this. ${ }^{47}$

Local-level reservations sparked some concern among even those supportive of such a measure, because these policies for "women" were blunt tools and not a panacea for the problems particular to the women of the lowest castes..$^{8}$ Another activist recognized the mixed success of the local-level

47. Author's interview with Brinda Karat, ro December 1996, New Delhi.

48. Dana Dunn, "Gender Inequality in Education and Employment in the Scheduled Castes and Tribes of India", Population Research and Policy Review, 12 (1993), pp. 53-70. Likewise, in spite of policies aimed at the socioeconomic uplift of the scheduled castes and tribes, the women within these groups remain "doubly disadvantaged": "The multiplicity of social categories in India often 
reservations but argued that if only a few of the elected women feel that they are an important part of the political process, that is an advance. ${ }^{49}$

Karat not only considers this diversity within women, but also the failure of many women's organizations to build bridges to other disadvantaged groups, a fact that exacerbates competing inequalities. Many women's organizations have not been terribly supportive of lower castes or of the extension of job reservations to OBCs. Having learned from minority women's critiques of the United States' women's movement, Karat's organization has promoted the notion that "sisterhood means you have to come out and openly support dalit [untouchable] women". But when OBCs were given reservations, there were "middle-class women in the streets of Delhi threatening to kill themselves and coming out with the most obscene signs" as well as "a section who preferred to remain silent". Only four or five national women's organizations defended OBCs' job reservations. ${ }^{5 \circ}$ This backdrop increases the tensions between supporters of women's reservations and those of $\mathrm{OBC}$ reservations in legislatures.

Women's organizations have been ambivalent towards Muslim demands for reservations as well. Karat claims that Muslims are underrepresented in Parliament, but a Muslim reservation would do little for Muslim women without the women's reservation as well. "This is the only way that Muslim women are going to be able to come out into public life, because even if you have community representation, they will never allow Muslim women to come in and represent. No way. ${ }^{\text {SI }}$ Muslims, on the other hand, fear that a women's reservation would essentially be a Hindu women's reservation. Such qualms parallel Muslim fears in the 1930s that extending even the right to vote, let alone reserved seats, to women would increase the political power of the Hindu majority, due to the larger number of educated Hindu women. Thus Muslim resistance to some political rights for women is not just due to cultural conservatism but to electoral calculations. In recent years some Muslim groups have been demanding the reserved seats that they lost at Independence. ${ }^{52}$ This demand also came up in the context of parliamentary debate over women's reservations.

Some women understand the logic behind the demands for reservations on a class or religious basis, but feel that women's reservations should come first. Feminist and Christian leader Jotsna Chatterjee admits that "we have

serves to obscure the status of women in the most disadvantaged segments of the population" (p. 66).

49. Author's interview with Vimla Farooqui of the National Forum for Indian Women (NFIW), Delhi, 2 December 1996.

50. Author's interview with Brinda Karat, ro December 1996, New Delhi.

51. Ibid.

52. Theodore P. Wright, "A New Demand for Muslim Reservations in India", Asian Survey, 37 (1997), pp. 852-858. 
no objection to the OBCs getting reservations", but first, women should be given thirty-three per cent reservation, and "automatically this will apply to every category". That would mean "that women will have to be given space in the scheduled caste, scheduled tribe section, and then if it is extended to the OBCs, it will have to be also given in the OBCs and also in the minorities" ${ }^{\prime 3}$ Chatterjee represents a religious minority community, Christians, but since their educational and socioeconomic status tends to be higher than that of Muslims, Christians have not been inspired to lodge a similar demand for sub-reservations within women's reservations.

These activists remain supportive of women's reservations, although they recognize that this policy is a blunt tool which does not adequately address the doubly disadvantaged $\mathrm{OBC}$ or Muslim women. Politicians in parliamentary debates, however, may have raised concerns about Muslim and OBC women in order to defeat the Women's Reservation Bill. Alva has charged: "When it was introduced [...] there was hullabaloo in the House [...] No man has the courage to stand up in the House and say we don't want it, so they had to sabotage it. Now the only way they could sabotage it is to appeal to caste. Because caste cuts across women. ${ }^{\text {"4 }}$ Some activists supportive of women's reservations describe this as a strategy to divide women on the basis of caste, class and creed, or as "splitting hairs" to divide and rule or at least maintain seats in Parliament." One commentator memorably predicted that the Women's Reservation Bill "will be diluted and further diluted till you have a law that says you can have your one third reservation for women provided they have pink hair, are totally backward, completely unheard of in any political arena". ${ }^{56}$

An ambiguous example of this approach came from Uma Bharati, a Member of Parliament from the Bharatiya Janata Party (BJP). She herself is difficult to categorize, a female member of the backward classes in a party dominated by Hindu upper castes. Although her party platform supported the bill and she claimed to support it as well, she became a spokeswoman for the demand to amend the bill to include OBCs, an amendment that led to its downfall. Ironically, the BJP had vociferously decried the extension of reserved central government jobs to OBCs in 1990, a campaign that led to several self-immolations by upper-caste students. At that point the BJP, which is a nationalist organization promoting the idea of India as a Hindu nation, was quick to criticize the $\mathrm{OBC}$ reservations as divisive and a threat to national integrity. Although this sudden concern for OBCs in the context

53. Author's interview with Jotsna Chatterjee, women's movement leader and YWCA activist, New Delhi, 22 November 1996, New Delhi.

54. Author's interview with Margaret Alva, I9 December 1996, New Delhi.

55. Author's interview with activists, Miss Gangoli of the YWCA in Delhi, 3 December 1996, and Jotsna Chatterjee, 22 November 1996.

56. Maneka Gandhi, "And the One Who Differs [...] Maneka Gandhi on the Women's Reservation Bill", Manushi, 96 (1996), p. 18. 
of the women's reservations bill seems suspicious, Uma Bharati's credentials to make such a proposal are hard to fault: "Since I am from the backward castes, I know from experience that women from the oppressed classes are the weakest of the weakest section of society. ${ }^{.57}$

In short, the discourses of "communities" came up again in the debate over women's reservations in the nineties, at times in ways reminiscent of the British and at times in ways similar to the Committee on the Status of Women. National unity was a minor theme in this latest round. Even the BJP remained unusually silent about the threat such group-based policies posed for Hindus and national integrity, letring the Women's Reservation Bill fail largely due to squabbling over proposals to include OBCs. The competing inequalities at the basis of gender, class, caste and religious minority movements for reservations have not yet reached a detente.

\section{CONCLUSIONS: COMPLICATING THE CATEGORIES}

For women to get rights is not a very simple thing.

Vimla Farooqui, National Forum for Indian Women. ${ }^{58}$

The history of demands for women's reservations in India illustrates the many ways administrators, politicians and activists have socially constructed women's identities and interests. Like the British administrator who categorized women as "minor minorities" in comparison with caste and religious groups, after Independence the Committee on the Status of Women in India contrasted women as a "category" with "communities" based on caste or religion, which were still considered more legitimate political groupings. The extension of reservations to women in local level legislative bodies signaled a shift towards the acceptance of the category of "women" as a legitimate target of such public policies; yet the recent uproar in Parliament over the Women's Reservation Bill demonstrates that women's goals are still seen as competing with other groups rather than complementing them. Muslims fear Hindu women will dominate the reserved seats; lower classes and castes argue that privileged women will prevail. A few politicians see the parallels between different disadvantaged groups. For example, former prime minister V.P. Singh, who in 1990 expanded the scope of reservation policies to include OBCs, likewise argues that India "can't have social justice without justice to women". ${ }^{99}$

The history of debates over women's reservations, particularly the competition between various unequal groups, is a particularly rich example of the

57. BJP MP Uma Bharati, quoted in Meenakshi Nath, "Cutting Across Party Lines: Women Members of Parliament Explain Their Stand on Reservation Quotas", Manushi, 96 (1996), p. II. 58. Author's interview with Vimla Farooqui, Delhi, 2 December 1996.

59. Author's interview with former prime minister of India, V.P. Singh, New Delhi, 20 November 1996. 
complexity of overlapping identities and the tendency of material factors to bring different identities into relief at different historical points. This issue also demonstrates how "complicating the categories" leads to not only academic but practical challenges. The colonial categorizations of Indian society were both too complicated and not complicated enough. British attempts to simultaneously appease and divide the "major minorities" caused them to subsume vast diversity under the categories of a Hindu "majority" and Muslim "minority" as well as develop a similarly oversimplified yet divisive codification of the caste system. These primary categories were superimposed onto gender-based provisions.

This legacy effected the debate over women's reservations in the 1974 report, Towards Equality, which recommended only limited, local-level women's reservations, in large part due to overriding concerns about caste and religious communities. Two major concerns expressed in the report were the more legitimate claim of such "communities" for reservations, as opposed to the claim of women, who constitute a mere "category", and, conversely, the fear that any reservations - particularly for "communities" - could lead to the disintegration of India. The contemporary arguments against reservations for women continue these streams of historical arguments. The priority given to the category of women has fallen behind Muslims and backward classes on the one hand and the nation on the other. What makes the persistence of these same arguments remarkable is the very different motivations at play in the three time periods under consideration, ranging from a colonial power trying to maintain control of an unruly colony, to a government committee genuinely concerned about the plight of women, to policy makers hoping to retain their seats in Parliament.

Why is gender repeatedly singled out as a problematic category for groupbased policies? Is there a sound basis for past distinctions between the category of gender and communities of religious minorities or lower castes? Do these latter communities more neatly coincide with class, legitimating their claims to special policies? Every sort of group in India has internal diversity. There are well-off Muslims and relatively "forward" backward classes; yer women have the most internal diversity, since they are a substantial part of all class groups. If the only purpose of the policies is to help redistribute power and resources to the poor, gender alone may not be an appropriate category; yet ignoring gender and using other categories can be equally problematic, since women within other disadvantaged categories are often the worst off. ${ }^{60}$ Moreover, reservations are not simply a redistributive policy since they are also a means for group recognition and representation. For this purpose, women may be as relevant a group as any, even if they are

6o. Dana Dunn, "Gender Inequality in Education and Employment of the Scheduled Castes and Scheduled Tribes of India", Population Research and Policy Review, I2 (1993), pp. 53-70. 
scattered throughout the class hierarchy. As Benedict Anderson has famously pointed out, even people who may never meet can become "imagined communities" ${ }^{61}$ On the other hand, the extremely diverse category of women is particularly prone to politically-motivated reimaginings. Thus politicians could appeal to half of the Indian electorate when promising parliamentary reservations for women, but in the later debates they could argue, for any other constituency, that those seats would be taken by the women of a rival group. Due in part to such political manipulations and to the nature of the category itself, women's organizations in India have not achieved unity, let alone a broader solidarity between women, Muslims and backward classes. Given the diversity within and between these groups, what could facilitate the formation of broader coalitions? One possibility is revising or complicating the categories of group based policies to discourage groupbased competition.

Reservations, which tie material and political benefits to peoples' identification with certain social categories, are a recipe for explosive politics. Yet such targeted policies may be necessary to deal with inequalities. India is faced with the dilemma of a country with an incredibly complex patchwork of overlapping identities and at the same time profound inequalities and stratification on the basis of many of these identities. Group-based policies can alleviate this stratification, yet the best way to categorize society for this purpose is far from clear. Although India is an extreme case due to the sheer number of dimensions of cultural identity and the degree of stratification, the dilemma facing it is not unique to India. The biggest challenge to affirmative action policies today - in both Western and non-Western societies - is defining the boundaries of the beneficiary categories. In the United States, for example, race- and gender-based policies are under fire, and proposals incorporating class and multifaceted notions of "disadvantage" are proliferating.

India's much longer history of affirmative action is instructive in this regard. Although the category of "backward" citizens is proliferating perhaps too quickly, the "other backward classes" or OBC category is an interesting attempt to incorporate several different indicators of disadvantage. Trying to recognize the so-called "backward" within other broader categories such as women could avoid reifying the category of women and reach the most disadvantaged members of society. Yet the ongoing controversies over defining categories and subcategories may prevent any policy innovations at all. Given the complexity of Indian women's identities, policy makers and activists must walk the grey line between exploring more complex policies and courting political gridlock. Competing inequalities may impede the political unity of the disadvantaged; nevertheless, if policies to benefit 
disadvantaged groups are passed despite the "hulabaloo in the House", these competing forces may also result in more nuanced policies.

It is not the purpose of this article to make policy recommendations or to advocate a position on women's reservations; yet a theoretical recognition of the complexity of social categories and the intertwined nature of identities and interests does have practical implications. When lines of social and material stratification coincide, group-based policies such as reservations may be necessary. Rather than reinforcing social categories, as many critics argue, judicious use of such policies may be the only way to combat extreme disadvantage. However, a side effect of such policies is the tendency, seen in these case studies, for disadvantaged groups such as women, backward classes and religious minorities to compete over group-based benefits rather than form coalitions. One promising policy approach for India, suggested recently in terms of employment and educational reservations, is to target not the standard major and minor minorities but to allocate benefits to those who break down such barriers.

One example is reservations for people in intercaste marriages. To avoid penalizing low-caste women who take on the official status of their highercaste husbands, the Ministry of Welfare has recently considered reserving jobs for such mixed families. Former government minister Ram Vilas Paswan also has advocated a new reservation category for those who have intercaste marriages:

In India you can change religion, you can change the party, you can become rich, rich can become poor, but you can't change your caste. So caste is just like a rock. So the only process where the caste system can be weakened is intercaste marriage [...]. If the reservation is made on that ground, intercaste marriage, then slowly, slowly caste system will be abolished. And if there is no caste then there will be no reservation on the basis of caste. ${ }^{62}$

In this way, material benefits become associated with those who do not fit into categories rather than with the reified categories of gender, caste, class or religion. Such innovations may be a promising way to alleviate the competing inequalities along these lines and to reflect in practice our academic attempts to "complicate the categories" of Indian society. By disconnecting material benefits from official gender, religious or class categories, such policies can facilitate a sense of shared interests rather than competition between disadvantaged groups, one step toward building coalitions.

Rather than entering a "post-material" age of identity politics, both the Western and non-Western worlds face increasingly complicated relationships between interests and identities. As critic Shane Phelan observes:

62. Author's interview with Ram Vilas Paswan, General Secretary of the SC/ST MPs Forum, Minister of Railways, MP from Bihar, Hindu dalit Leader, Delhi, 2o December 1996. 
Interest talk may make sense if all the members of a group share every "relevant" social characteristic or submerge difference(s) among themselves, but this eventuality is increasingly unlikely. In modern societies, where overlapping social movements and identities are increasingly present, interest becomes as unstable as identity. ${ }^{63}$

In the theoretical speculations over what may be replacing "class" politics in Europe and the West, then, we should avoid drawing a false dichoromy between material and post-material politics, often equated with a shift from class-based movements to "new social movements" based on gender and other "identities". This tendency overshadows the fact that classes may share a sense of group identity, not just interests; likewise, groups based on gender, religion or caste may rally around shared interests, not just identities. This is true in the West as well, but becomes particularly apparent in case studies from a non-Western society like India. Moving away from the European and American approaches to these debates forces us to challenge the dichotomy between material and post-material politics, which is misleading even in Western cases and inapplicable to most non-Western cases. Moreover, women's movements in both Western and non-Western societies also pose a serious challenge to such dichotomies, since they are based not just on gender identities but also material questions ranging from access to food to access to political office. Theory built from a non-Western case such as India can produce a more nuanced alternative to the material versus post-material or class versus identity schisms in the literature. 